\title{
PENYALAHGUNAAN KEADAAN OLEH NEGARA DALAM PRAKTIK PERJANJIAN PADA KAJIAN HUKUM PRIVAT
}

Oleh:

\author{
Ronald Saija ${ }^{1}$
}

Fakultas Hukum Universitas Pattimura

\begin{abstract}
Abstrak
Dalam kehidupan sehari-hari, manusia saling melakukan kerjasama untuk memenuhi kebutuhan hidupnya seperti melakukan pertukaran barang atau ragam bentuk perjanjian yang sudah kompleks. Artikel ini bertujuan untuk mengetahui dan memahami dasar legitimasi negara turut campur dalam bidang hukum privat (perjanjian) serta mengetahui dan memahami kriteria klausula eksemsi dalam kontrak baku sehingga dapat digolongkan sebagai penyalahgunaan keadaan. Artikel ini mempergunakan metode yuridis normatif dengan pendekatan perundang-undangan dan kasus. Pengumpulan data dilakukan melalui inventarisasi, identifikasi dan sistematisasi terhadap bahan hukum primer dan sekunder, interpretasi (penafsiran) dan konstruksi dengan menggunakan penalaran deduktif. Bahan hukum dianalisis secara argumentasi yuridis terdiri atas diskursus hukum, retorika hukum dan logika hukum. Hasil penelitian menunjukkan bahwa: 1) Campur tangan negara ke dalam bidang ekonomi sosial, termasuk hukum kontrak adalah untuk membuat peraturan, menyelenggarakan pemerintahan dan fungsi mengadili dengan tujuan melindungi segenap bangsa Indonesia sebagaimana termaktub dalam Undang-Undang Dasar Negara Republik Indonesia 1945 serta Sila ke 5 Pancasila; dan 2) Penyalahgunaan keadaan sebagai salah satu doktrin dalam pandangan pengadilan masih secara terbatas dijadikan pertimbangan dalam menjatuhkan putusan yang berkaitan dengan kontrak kredit, sedangkan pada kontrak perlindungan konsumen, ketika terjadi benturan kepentingan di antara para kontraktan meskipun telah dikualifisir sebagai penyalahgunaan keadaan, namun dijadikan dasar-dasar pertimbangan dalam menjatuhkan putusan.
\end{abstract}

Kata kunci: Penyalahgunaan Keadaan, Kontrak, Pengadilan.

Abstract

In daily life, people perform cooperation with one another in order to fulfill their needs such as exchanging goods or various forms of complex agreements. This article aims to identify and understand the basis of legitimacy of the state to intervene in the field of private law (agreement) as well as to identify and understand the criteria of exemtion clauses in standard contract that can be classified as a misuse of state. This is a normative legal research that employs statute and case approaches. The data are collected through the inventory, identification and systematization of the primary and secondary legal materials, interpretation (interpretation) and construction by using deductive reasoning. Legal materials analyzed in juridical arguments which consist of legal discourse, the rhetoric of law and legal logic. The result shows that: 1) The interferences of the state into the field of social economy, including contract law, are in the making of Laws and Regulations, state administrating and adjudicating function with the aim of protecting the entire Indonesian nation as stipulated in the 1945 Constitution of Republic Indonesia and moral principle number 5 of Pancasila; and 2) Misuse of state as one of the doctrines in view of the court is still limited to be taken as consideration in making decisions towards a loan contract, while for the case of consumer protection

Keywords: Misuse of State, Contract, Court.

\section{PENDAHULUAN}

\subsection{Latar Belakang}

Dalam kehidupan sehari-hari, manusia saling melakukan kerjasama untuk memenuhi kebutuhan hidupnya seperti melakukan pertukaran barang atau ragam bentuk perjanjian yang sudah kompleks. Herodotus, seorang penulis Yunani abad ke-lima sebelum Masehi, menjelaskan bahwa jalinan hukum pertukaran barang antara para pihak telah terjadi sejak dulu dimana proses ini akan terus berulang sampai tercapai kesepakatan tentang nilai tukar yang dapat diterima oleh kedua belah pihak. ${ }^{2}$ Bakti, h.5

\footnotetext{
${ }^{1}$ Ronald Saija adalah Doktor Ilmu Hukum yang merupakan dosen pada Fakultas Hukum Universitas Pattimura.

2 Herlien Budiono. 2006. Asas Keseimbangan bagi Hukum Perjanjian Indonesia. Bandung: Penerbit Citra Aditya
} 
Latar belakang lahirnya kontrak bisnis modern (in casu kontrak baku) didasarkan pada perbedaan kondisi ekonomi dan tingkat pengetahuan diantara para pihak, disamping keterdesakan akan kebutuhan, sehingga pihak yang berada pada posisi atau kedudukan ekonomi yang lebih kuat dan memiliki pengetahuan yang lebih baik akan memanfaatkan keadaan tersebut guna memproteksi kepentingan hukumnya melalui klausula baku. Secara a contrario, pihak yang berada pada posisi kurang menguntungkan karena kekurangan modal, pengetahuan terbatas, apalagi karena desakan kebutuhan, justru akan menjadi sasaran untuk dimanfaatkan. Take it (setuju), pihak yang kebetulan berada pada posisi lemah dari segi ekonomi, pengetahuan terbatas dan terdesak oleh suatu kebutuhan harus rela menerima klusula baku meski dimensi keadilan sangat digerogoti.

Adapun faktor-faktor yang menjadi penyebab kelaziman kontrak baku menjadi berat sebelah dan menempatkan kreditor "selalu" berada dalam posisi yang lebih kuat, umumnya" para ahli hukum dalam berbagai referensi berpendapat, bahwa: "1.Kurang adanya atau bahkan tidak adanya kesempatan bagi salah satu pihak (ekonomi lemah) untuk melakukan tawar-menawar atau negosiasi, sehingga pihak yang disodorkan kontrak tidak memiliki kesempatan yang banyak untuk dapat memahami secara mendalam materi dari kontrak; 2.Penyusunan kontrak dilakukan secara sepihak, berkonsekuensi pihak yang kuat lasimnya memiliki cukup banyak waktu untuk memikirkan mengenai klausula-klausula dalam kontrak dimaksud, bahkan dapat diyakini bahwa kontrak yang disodorkan adalah merupakan produk dari seorang yang ahli dalam penyusunan kontrak, sedangkan pihak posisi lemah tidak memiliki banyak kesempatan untuk mempelajari dan bahkan tidak familiar dengan klausula-klausula dimaksud; 3. Pihak ekonomi lemah menempati kedudukan yang sangat terdesak dan tertekan, sehingga hanya dapat bersikap "take it or leave it".

Klausula-klausula berat sebelah yang dituangkan dalam praktik kontrak baku merupakan cerminan dari penyimpangan asas kebebasan berkontrak dan asas konsensualisme. Dalam praktik kontrak bisinis seperti sekarang ini, perbuatan hukum dimaksud dapat dikategorikan sebagai penyalahgunaan keadaan. Lembaga penyalahgunaan keadaan dalam sistem hukum perdata (perjanjian) di Indonesia ironisnya belum dikenal, sehingga dalam penyelesaian sengketa yang bermuatan penyalahgunaan keadaan dalam suatu kontrak bisnis masih belum memiliki kepastian hukum, karena belum diatur dalam suatu peraturan perundang-undangan nasional (hukum positif). Di samping itu, masih terdapat kesulitan dalam merumuskan karakteristik tentang penyalahgunaan keadaan. Berbeda halnya di Belanda, dengan dicantumkannya ajaran "misbruik van omstandigheden" (penyalahgunaan keadaan) pada undangundang, yang dituangkan ke dalam Nieuw Burgerlijk Wetboek (NBW) yang mulai berlaku di Nederland pada tanggal 1 Januari 1992, maka dapat dikatakan bahwa hukum perjanjian di Belanda telah mengalami perkembangan yang sangat fundemental, apabila dibandingkan dengan Indonesia. Pengaturan tersebut yang dituangkan kedalam NBW merupakan landasan hukum bagi hakim dalam memutus suatu perkara, terhadap suatu kontrak baku (standar) yang di dalamnya terdapat penyalahgunaan keadaan.

Berdasarkan uraian tersebut di atas, dua rumusan masalah yang diangkat dalam artikel ini yaitu: 1) Apakah yang menjadi dasar legitimasi sehingga negara turut campur dalam bidang hukum privat (perjanjian) ? dan 2) Bagaimanakah pendirian pengadilan di Indonesia mengenai ajaran penyalahgu-

Airlangga, h. 10 .

6 Mariam Darus Badrulzaman. 1994. Aneka Hukum Bisnis. Bandung: Penerbit Alumni, h. 47. 


\section{Kertha Patrika}

Penyalahgunaan Keadaan oleh Negara Dalam Praktik Perjanjian pada Kajian Hukum Privat Ronald Saija

Nomor 350 MPP/Kep/2001 tentang pelaksanaan tugas dan wewenang BPSK, khususnya Pasal 42 ayat (1) menegaskan bahwa putusan BPSK merupakan putusan yang final dan memiliki kekuatan hukum yang tetap. Ketentuan yang mengatur tentang kekuatan putusan BPSK yang bersifat final dan mengikat menjadi kontradiktif, ketika dikorelasikan dengan ketentuan Pasal 56 ayat (2) UUPK yang memberikan kesempatan kepada para pihak untuk mengajukan keberatan terhadap putusan BPSK kepada Pengadilan Negeri. Hal ini tentu merupakan bukti inkonsistensi sekaligus kelemahan pengaturan tentang kekuatan putusan BPSK. Mengeleminir silang pendapat dan menghindari kerancuan pemahaman tentang terminologi dan substansi keberatan atas putusan BPSK, Mahkamah Agung menerbitkan Peraturan Mahkamah Agung Republik Indonesia Nomor 1 Tahun 2006 Tentang Tata Cara Pengajuan Keberatan Terhadap Putusan Badan Penyelesaian Sengketa Konsumen, bahwa keberatan adalah upaya bagi pelaku usaha dan konsumen yang tidak menerima putusan BPSK, serta keberatan hanya dapat diajukan terhadap putusan arbitrase yang dikeluarkan oleh BPSK. ${ }^{8}$ Adapun syarat yang harus di penuhi dalam pengajuan keberatan terhadap putusan arbitrase yang dikeluarkan BPSK adalah sebagaimana ditegaskan dalam ketentuan Pasal 6 ayat (3) dan (4) Peraturan Mahkamah Agung Republik Indonesia Nomor 1 Tahun 2006. Alasan lain di luar ketentuan Pasal 6 ayat (3) di atas, maka majelis hakim dapat mengadili sendiri sengketa konsumen yang bersangkutan dan dalam mengadili sendiri, majelis hakim wajib memperhatikan ganti rugi sebagaimana diatur dalam Pasal 19 ayat (2) UUPK (vide Pasal 6 ayat (5 ) dan (6) PERMA Nomor 1 Tahun 2006). ${ }^{9}$

Kendala-kendala yang terjadi berkaitan dengan pemanfaatan BPSK yaitu: 1) Prinsip kurangnya aksebilitas, dimana hingga Tahun 2014 di Indonesia baru terdapat 25 BPSK untuk kota ${ }^{10}$ dan kabupaten; 2) Kemauan politik dari pemerintah daerah/kota yang masih diwarnai keberpihakan pada kepentingan pelaku usaha sebagai motor penggerak pembangunan ekonomi dari pada memberikan perlndungan terhadap hak-hak konsumen (termasuk tersedianya lembaga penyelesaian sengketa konsumen yang efisien dan efektif); 3) sebagaimana diinventarisir Susanti Adi Nugroho, kendalanya: kelembagaan/ institusional; pendanaan; sumber daya manusia; peraturan; pembinaan dan pengawasan, serta tidak adanya koordinasi aparat penanggung jawab; kurangnya sosialisasi dan rendahnya tingkat kesadaran hukum konsumen; kurangnya respon dan pemahaman dari badan peradilan terhadap kebijakan perlindungan konsumen; kurangnya respon masyarakat terhadap UUPK dan lembaga BPSK; ${ }^{11}$ 4) menurut Mas Achmad Santosa adalah karena begitu luas dan besarnya beban yang dipercayakan, sehingga tugas dan wewenang BPSK tidak maksimal. ${ }^{12}$

8 Vide Pasal 1 ayat (3) jo Pasal 2 Peraturan Mahkamah Agung No. 1 Tahun 2006 tentang Tata Cara Pengajuan Keberatan Terhadap Putusan Badan Penyelesaian Sengketa Konsumen Studi di Pengadilan Negeri Kelas 1A Padang.

9 Seperti contoh Putusan BPSK Makassar No. 02/Abrt/BPSK/XII/2010 tanggal 12 Desember 2010 dianulir oleh putusan Pengadilan Negeri Makassar No. 02/Pdt.BPSK/2011/PN.Mks tanggal 24 Maret 2011 yang menyatakan bahwa BPSK kota Makassar tidak berwenang mengadili perkara a quo dan menyatakan bahwa putusan No. 02/Abrt/BPSK/XII/2010 tidak mempunyai kekuatan hukum mengikat bagi para pihak. Di tingkat kasasi, Mahkamah Agung Republik Indonesia dalam putusannya No.485 K/ Pdt.Sus/2011 menguatkan putusan Pengadilan Negeri Makassar No. 02/Pdt.BPSK/2011/PN.Mks yang menolak permohonan kasasi dari pemohon dengan pertimbangan bahwa judex factie tidak salah menerapkan hukum karena hubungan hukum antara para pihak adalah perjanjian utang piutang yang merupakan wewenang Pengadilan Negeri.

10 Susanti Adi Nugroho, Op.Cit., h. 76.

11 Ibid., h.210-236.

12 Kurniawan, Permasalahan dan Kendala Penyelesaian Sengketa Konsumen Melalui Badan Penyelesaian Sengketa Konsumen, Jurnal Dinamika Hukum, 2012, Vol. 12, No. 1, h.1. 
udara yang lain atau beberapa bandar udara dengan imbalan bayaran atau dalam bentuk imbalan jasa yang lain. ${ }^{15}$

Berdasarkan klausula eksemsi pada sub (1), tidak berarti pengangkut dengan sendirinya dapat melepaskan dan/atau membatasi tanggung jawab atas kerugian yang diderita oleh konsumen sebagai akibat pelaksanaan kewajiban yang tidak sesuai dengan kesepakatan atau timbulnya kerugian konsumen disebabkan kesalahan pengangkut, karena secara umum terdapat prinsip-prinsip tanggung jawab dalam hukum, yaitu: “(1) Tanggung jawab berdasarkan kesalahan (liability based on fault atau fault liability) berdasarkan Pasal 1365-1367 BW Indonesia; (2) praduga untuk selalu bertanggung jawab (presumption of liability) (3) praduga untuk tidak selalu bertanggung jawab (presumption of non liability) (4) tanggung jawab mutlak (strict liability) (5) pembatasan tanggung jawab (limitation of liability)" ${ }^{16}$

\subsection{Ganti Rugi atas Pembatalan dan atau Keterlambatan Pengangkutan}

Sesuai ketentuan paragraf 1 tentang wajib angkut, khususnya ketentuan Pasal 140 ayat (2) Undang-Undang Penerbangan Tahun 2009 ditegaskan bahwa badan usaha angkutan udara niaga wajib memberikan pelayanan yang layak terhadap setiap pengguna jasa angkutan udara sesuai dengan perjanjian pengangkutan yang disepakati. Komitmen dari perusahaan penerbangan negara dan swasta di Indonesia akan diuji konsistensinya apabila terjadi pembatalan dan atau keterlambatan pengangkutan oleh pengangkut, maka perusahaan penerbangan bertanggung jawab atas kerugian yang diderita karena pembatalan dan atau keterlambatan pada angkutan udara, kecuali pengangkut dapat membuktikan bahwa pembatalan dan atau keterlambatan tersebut disebabkan oleh faktor cuaca dan teknis operasional dan tanggung jawab pengangkut termasuk tidak terangkutnya penumpang sesuai dengan jadwal yang telah ditentukan. ${ }^{17}$ Pembebasan tanggung jawab pengangkut atas keterlambatan angkutan udara karena faktor cuaca dan teknis operasional disebutkan dalam Pasal 13 ayat (2) dan ayat (3) Peraturan Menteri Perhubungan Nomor 77 Tahun 2011 tentang Tanggung Jawab Pengangkut Angkutan Udara.

Kedua alasan pelepasan tanggung jawab karena keterlambatan tidak berarti pengangkut $100 \%$ bebas dari kewajiban memberikan ganti rugi atas delayed tersebut, melainkan tetap memberikan ganti rugi. Adapun terhadap tidak terangkutnya penumpang dengan alasan kapasitas pesawat udara (denied boarding passenger), maka pengangkut juga wajib memberikan ganti kerugian.

\subsection{Ganti Rugi Akibat Hilang, Musnah dan Rusak Barang Penumpang}

Kewajiban pemberian ganti rugi akibat hilang, musnah dan rusaknya barang penumpang (bagasi tercatat) merupakan penerapan prinsip praduga untuk selalu bertanggung jawab (presumption of liability) dan prinsip tanggung jawab dengan pembatasan (limitation of liability), kecuali untuk

\footnotetext{
15 Vide Pasal 1 ayat (29) jo Pasal 1 ayat (13) Undang-Undang No. 1 Tahun 2009 tentang Penerbangan.

16 Shidarta. 2000. Hukum Perlindungan Konsumen Indonesia. Jakarta: Penerbit Grasindo, h.59.

17 Vide Pasal 146 juncto Pasal 147 a Undang-Undang No. 1 Tahun 2009 tentang Penerbangan.
} 


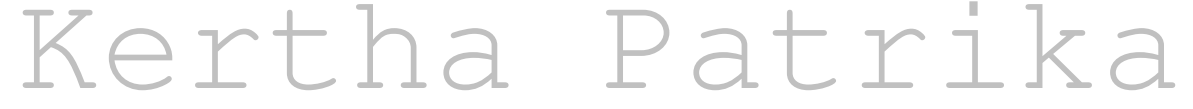

Penyalahgunaan Keadaan oleh Negara Dalam Praktik Perjanjian pada Kajian Hukum Privat Ronald Saija

atau musnah atau rusaknya barang kiriman, sejak pengirim barang (PT "T" bertindak untuk kepentingan konsumen) menerima salinan surat muatan udara dari pengangkut sampai dengan waktu yang ditetapkan sebagai batas pengambilan sebagaimana tertera dalam surat muatan udara (airway bill), meskipun disadari bahwa norma hukum dimaksud belum memberikan perlindungan hukum secara objektif. Terhadap kargo yang hilang atau musnah dibedakan dengan kargo yang rusak sebagian atau seluruh isi terkait dengan besaran ganti rugi, padahal jika kargo rusak sebagian atau seluruhnya sehingga tidak dapat digunakan sesuai dengan fungsinya - sama akibatnya dengan kargo yang hilang atau musnah. Menetapkan jumlah ganti kerugian secara sama rata sebesar Rp. 100.000 (sepuluh ribu rupiah) per kilogram terhadap kargo yang hilang atau musnah dari aspek keadilan perlu dikaji lebih mendalam oleh hakim di pengadilan khusus ketika terjadi sengketa, karena pertimbangan unsur subjektif dan objektif dari muatan kargo.

Dalam Undang-Undang Penerbangan Tahun 2009 dan Peraturan Menteri Perhubungan Nomor 77 Tahun 2011 hanya mengatur tanggung jawab pengangkut terhadap keterlambatan penerbangan dan penyerahan bagasi sehingga menimbulkan kerugian bagi penumpang dan oleh karenanya pengangkut harus bertanggung jawab memberikan kompensasi, sedang keterlambatan terhadap penyerahan kargo tidak ditetapkan sanksi berupa pemberian ganti kerugian. Dalam kekosongan pengaturan kondisi seperti ini, perlu amandemen ketentuan dimaksud supaya konsumen dapat terlindungi secara maksimal, berupa norma pengaturan keterlambatan penyerahan kargo minimal dipersamakan dengan ketentuan sanksi keterlambatan penyerahan bagasi tercatat.

Sekalipun di dalam kontrak pengiriman barang PT " $\mathrm{T}$ ” terdapat klausula pelepasan tanggung jawab terkait keterlambatan akibat force majeur yang masih dapat ditoleransi, namun menjadi problem hukum ketika tetap terjadi keterlambatan tapi bukan karena faktor overmacht melainkan disebabkan faktor internal perusahaan, seperti kesalahan/kelalaian karyawan atau manajeman yang tidak profesional, maka dalam kondisi ini perihal tanggung jawab tidak terekspos dalam klausula kontrak, begitupun ketentuan hukum positif tidak mengatur, padahal potensi kerugian yang diderita konsumen akibat keterlambatan barang kiriman sangat rentan.

Olehnya, dibutuhkan transparansi dari PT "T" apakah obyek kontrak (barang kiriman) diasuransikan untuk mengantisipasi terjadinya sesuatu yang tidak diinginkan. Hal ini penting diketahui karena dalam consignment note (BTTKB) terdapat 2 (dua) item biaya, yaitu biaya kirim (freight) dan biaya (add/charge). Freight terkait besaran biaya timbangan, dalam pengertian semakin berat barang kiriman makin besar ongkos kirim dan dipatok perkilo sebesar Rp. 12.000 (dua belas ribu rupiah per kilogram) tetapi untuk item add/charge tidak terdapat penjelasan untuk itu (apakah termasuk di dalamnya biaya premi asuransi ?).

\section{Kontrak Kredit Bank "S" dan "B"}

Setiap orang tentu memerlukan dana (uang) untuk memenuhi kebutuhan, dan salah satu alternatif yang dapat di tempuh dalam merealisasikan kepentingan itu adalah dengan mengajukan permohonan kepada lembaga pembiayaan (bank), yang biasa disebut permohonan kredit. Agar permohonan kredit dapat di respon secara baik oleh pihak bank, maka hanya terdapat 1 (satu) 
hardship ditempatkan pada urutan sistematika lebih dahulu ${ }^{21}$ tentang Performance (pelaksanaan) sedang overmacht ditempatkan pada Bab VII tentang Ketidakpelaksanaan (nonperformance). Lebih lanjut dinyatakan perbedaan lainnya sebagai berikut: "Overmacht apabila terbukti, maka: (i) Pada saat itu juga kontrak berakhir (kecuali untuk overmacht sebagian, ada kewajiban untuk melanjutkan sebagian yang tersisa) karena apabila merujuk substansi Pasal 1381 BW, maka overmacht merupakan salah satu alasan yang menyebabkan hapusnya perikatan; (ii) Debitor tidak lagi bertanggung gugat atas risiko yang timbul.

Lemahnya posisi konsumen dalam kontrak kredit perbankan berklausula penyesuaian suku bunga (naik) oleh pemerintah menerbitkan produk regulasi dan legislasi dengan tujuan melindungi kepentingan konsumen dan masyarakat. Kebutuhan blue print perbankan nasional dan sebagai kelanjutan program restrukturisasi perbankan Tahun 1988, maka tanggal 9 januari 2004 Bank Indonesia meluncurkan Arsitektur Perbankan Indonesia (selanjutnya disebut API). Regulasi dari Bank Indonesia dalam bentuk API kenyataannya mirip dengan BPSK berstatus "mati suri”, sehingga oleh pemerintah bersama dengan Dewan Perwakilan Rakyat mengesahkan lahirnya Undang-Undang Nomor 21 Tahun 2011 Tentang Otoritas Jasa Keuangan yang berfungsi menyelenggarakan sistem pengaturan dan pengawasan yang terintegrasi terhadap keseluruhan kegiatan di dalam sektor jasa keuangan.

Ketentuan mengenai perlindungan nasabah yang diatur dalam Undang-Undang Otoritas Jasa Keuangan Tahun 2011, ditindaklanjuti dengan terbitnya Peraturan Otoritas Jasa Keuangan Nomor 1/ POJK.07/2013 tentang Perlindungan Konsumen Sektor Jasa Keuangan (selanjutnya disebut POJK. 07/2013). Dalam Pasal 21 Peraturan Otoritas Jasa Keuangan 07/2013 mewajibkan bank untuk memenuhi keseimbangan, keadilan dan kewajaran dalam membuat kontrak dengan nasabah.

Praktik kontrak kredit yang lasim digunakan oleh bank adalah model kontrak baku, namun sesuai ketentuan Pasal 22 ayat (1) Peraturan Otoritas Jasa Keuangan 07/2013, maka kontrak baku harus disusun sesuai dengan peraturan perundang-undangan, termasuk dan tidak terbatas pada UUPK. Secara imperatif mengenai larangan kontrak baku dalam praktik kontrak kredit perbankan diatur dalam Pasal 22 ayat (2) Peraturan Otoritas Jasa Keuangan 07/2013. Dengan demikian, bank harus bertanggung jawab atas kerugian yang timbul dari kesalahan atau kelalaian pengurus, pegawai bank dan atau pihak ketiga yang bekerja untuk kepentingan bank yang bersangkutan (Pasal 29 POJK.07/2013) dan oleh karena itu, bank dalam mengelola usahanya harus profesional dalam setiap jenis produk yang ditawarkan kepada konsumen.

\section{Pendirian Pengadilan Indonesia Tentang Ajaran Penyalahgunaan Keadaan Dalam Kontrak Konsumen}

Dalam praktik penanganan perkara, seringkali dijumpai keadaan kekosongan aturan hukum (selain terjadi kekaburan dan konflik norma). Contohnya adalah belum adanya perundang-undangan yang mengatur tentang penyalahgunaan keadaan dalam suatu kontrak bisnis, yang merupakan nilai-

\footnotetext{
21 Bab VI Rancangan Undang-Undang Kontrak.
} 


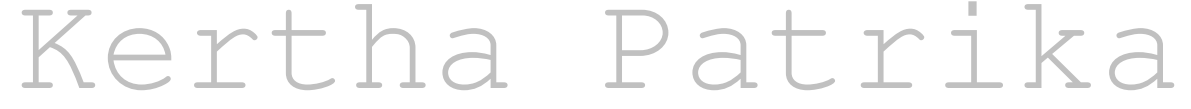

Penyalahgunaan Keadaan oleh Negara Dalam Praktik Perjanjian pada Kajian Hukum Privat Ronald Saija

Putusan Mahkamah Agung Republik Indonesia Register Nomor 1966 K/Pdt/2005 tanggal 14 Februari 2007 tentang perkara mobil hilang di area parkir, yang kronologis perkara terurai secara ringkas di bawah ini: "Ny.T.Imelda Wijaya (penggugat/terbanding/termohon kasasi) memarkir mobil Isuzu Panther LS Tahun 2000 di area parkir yang dikelola oleh PT. Anugrah Bina Karya (tergugat/ pembanding/pemohon kasasi) di pasar mandiri - Mal Kelapa Gading Jakarta Utara, sesuai kartu/struk tanda parkir PM002/DWR/causal no.009936, namun setelah kembali berbelanja - mobil yang diparkir telah hilang".

Pada dasarnya Mahkamah Agung Republik Indonesia menguatkan putusan Pengadilan Tinggi Jakarta Reg. No. 178/Pdt/2004/PT.DKI tanggal 18 Agustus 2004 (yang juga menguatkan Putusan Reg. No.16/Pdt/G/2003/PN.Jkt.Ut tanggal 21 Juli 2003) yang dalam amarnya antara lain menyatakan bahwa tergugat telah melakukan perbuatan melawan hukum dan menyatakan secara hukum bahwa klausula yang menyatakan PT. Anugrah Bina Karya tidak bertanggung jawab atas kehilangan kendaraan milik Ny. T. Imelda Wijaya sebagaimana tercantum dalam kartu/struk tanda parkir adalah batal demi hukum.

Perkara yang sama mengenai sengketa parkir terekam dalam Putusan Mahkamah Agung Republik Indonesia Reg. No. 2078 K/Pdt/2009 tanggal 30 Nopember 2010. Dalam pertimbangan putusan dinyatakan bahwa berdasarkan yurisprudensi hubungan hukum antara pemilik kendaraan dengan pengusaha parkir adalah perjanjian penitipan, yang jika dihubungkan dengan Pasal 1365, 1366 dan 1367 KUHPerdata maka tergugat berkewajiban menanggung kehilangan sepeda motor penggugat di tempat pengelolaan tergugat. Putusan MA RI dimaksud merupakan mata rantai dari putusan Pengadilan Negeri Jakarta Pusat Reg. No.345/Pdt.G/2007/PN.Jkt.Pst tanggal 07 Mei 2008 yang dikuatkan oleh putusan Pengadilan Tinggi Jakarta Reg. No. 513/Pdt/2008/PT.DKI.Jkt, tanggal 22 Desember 2008 dengan amar antara lain menyatakan tergugat telah melakukan perbuatan melawan hukum dan menghukum tergugat untuk tidak lagi mencantumkan klausula baku yang mengalihkan tanggung jawab pada tiket parkir.

Dalam pertimbangan Putusan Pengadilan Negeri Jakarta Pusat yang dikuatkan oleh Pengadilan Tinggi DKI sebagaimana di kutip di atas, dinyatakan bahwa "fakta hilangnya sepeda motor penggugat apabila dihubungkan dengan perjanjian "penitipan barang" yang telah terjadi antara penggugat dan tergugat, maka tergugat sebagai pengelola perparkiran mempunyai tanggung jawab hukum atas kehilangan tersebut, sebab petugas/karyawan tergugat selaku pengelola parkir bertanggung jawab atas pengawasan dan pengamanan terhadap barang yang dititipkan secara memadai.

Mengkaji perkara parkir (Putusan MA RI No. 1966 K/Pdt/2005 dan putusan MA.RI No. 1264 K/Pdt/2005, serta Putusan MA RI No. 2078 K/Pdt/2009) yang dalam pertimbangannya mendasarkan pada Perbuatan Melanggar Hukum bukanlah merupakan suatu kesalahan bila ditinjau dari optik keadilan, tetapi bila mencermati perkembangan ilmu hukum kontemporer, idealnya hakim dalam putusan perkara parkir didasarkan pada pertimbangan cacat kehendak (baru) yaitu penyalahgunaan keadaan, mengingat fakta hukum yang menyelimuti perkara bersumber dari pemberian kesepakatan yang tidak bebas karena bagi konsumen yang telah memasuki areal parkir tidak memiliki pilihan - kecuali tunduk dan patuh pada syarat-syarat kontrak yang dicantumkan dalam struk/tanda karcis parkir ketika disodorkan/diambil, meskipun taruhan risiko sangat memberatkan. 
danya; lagi pula dalam gugatan balasan Bray menuntut kembali segala sesuatu yang telah dibayarnya terdahulu kepada perusahaan".

Sayangnya untuk kondisi sekarang, doktrin misbruik van omstandigheden atau unconscionability tidak dan/atau belum populer dalam lingkungan pengadilan, sehingga posisi ekonomi lemah belum terlindungi kepentingan hukumnya akibat kontrak baku yang berklausula eksemsi. Dalam menegakkan hukum ada tiga unsur yang selalu harus diperhatikan, yaitu kepastian hukum (rechtssicherheit), kemanfaatan (zweckmassigkeit) dan keadilan (gerechtigkeit) serta harus ada kompromi antara ketiga unsur tersebut dan mendapat perhatian secara proporsional seimbang. ${ }^{24}$ Menentukan skala prioritas dari suatu tujuan hukum membutuhkan pengkajian yang mendalam dari berbagai dimensi, karena apabila keliru akan berdampak reaksi negatif dari komunitas masyarakat hukum.

Kebijakan "release and discharge" merupakan fakta sejarah yang hingga kini menjadi polemik karena pada era ini, kepastian hukum berada pada posisi titik terendah dan menjadi tidak bernilai, digantikan dengan alasan kemanfaatan. Pertimbangan kebijakan ini semata-mata didasarkan untuk memperoleh kembali jumlah uang yang sangat besar dan sangat dibutuhkan akibat krisis keuangan dan ekonomi, sehingga sangat bermanfaat untuk kepentingan rakyat. Padahal jika ditilik dari pendekatan hukum pidana, maka uang negara dapat ditarik kembali melalui jenis penghukuman pidana, yaitu denda pengganti - selain hukuman badan/penjara sebagai efek jera, meskipun disadari butuh waktu yang agak lama.

Nilai positif peraturan perundang-undangan sebagai instrumen untuk menjamin kepastian hukum jika dipergunakan sebagai pilar dari pembangunan sistem hukum, yaitu: “(1). peraturan perundang-undangan merupakan kaidah hukum yang mudah dikenali (diidentifikasi), mudah diketemukan kembali, dan mudah ditelusuri sebagai kaidah hukum tertulis, bentuk, jenis dan tempatnya jelas, begitu pula pembuatnya. (2). peraturan perundang-undangan memberikan kepastian hukum yang lebih nyata karena kaidahnya mudah di identifikasi dan mudah diketemukan kembali. (3). struktur dan sistimatika peraturan perundang-undangan lebih jelas sehingga memungkinkan untuk diperiksa kembali dan di uji, baik segi-segi formal maupun materi muatannya. (4). pembentukan dan pengembangannya dapat direncanakan. Hal ini penting bagi negara yang sedang membangun sistem hukum baru yang sesuai dengan kebutuhan dan perkembangan masyarakat. ${ }^{25}$

Searah dengan hal di atas, Algra dan Duyyendijk menyatakan bahwa nilai lebih dari peraturan perundang-undangan dibandingkan dengan norma-norma lain, adalah: “(1). tingkat prediktabilitas yang besar. Hal ini berhubungan dengan sifat prospektif dari peraturan perundang-undangan, yaitu pengaturannya ditujukan ke masa depan. Oleh karena itu, perundang-undangan harus dapat memenuhi syarat agar orang-orang mengetahui tingkah laku apa yang diharapkan dari mereka pada waktu yang akan datang dan bukan yang sudah lewat. (2). kecuali kepastian yang lebih mengarah kepada bentuk formal, peraturan perundang-undangan juga memberikan kepastian mengenai nilai yang dipertaruhkan, terlepas apakah nilai itu bisa diterima atau tidak".

Peter Mahmud Marzuki mengemukakan pengertian kepastian hukum tidak terbatas pada segi

\footnotetext{
24 Sudikno Mertokusumo. 1993. Bab-Bab Tentang Penemuan Hukum. Bandung: Penerbit Citra Aditya Bakti, h.1-2.

25 Bagir Manan, Op.Cit., h.150-151.
} 
kemampuan intelektualitas dan moralitas sehingga menjadi hakim yang bersih, jujur dan profesional.

MA RI pada kenyataannya telah melakukan upaya dalam rangka peningkatan kapasitas hakim, melalui berbagai program dan aksi - namun kendala konvensional selalu menjadi hambatan, yaitu masalah pendanaan, seperti pernyataan di bawah ini : "MA telah mengupayakan peningkatan kapasitas hakim secara terus menerus dan berkesinambungan melalui beberapa program, antara lain : a) program pendidikan calon hakim; b) program pendidikan hakim berkelanjutan; c) beasiswa sekolah; dan d) pendidikan dan latihan kekhususan atau sertifikasi bagi tenaga teknis peradilan. Beberapa program tersebut belum seluruhnya dapat dilaksanakan secara maksimal dan optimal karena berbagai keterbatasan, seperti anggaran dan sumber daya manusia, sehingga tidak seluruh hakim mendapatkan pelatihan secara terpusat". ${ }^{29}$

Beijing statement of principle of independence of judiciary in the law asia region, kemudian diubah di Manila Tahun 1997 menegaskan bahwa untuk menegakkan kebenaran dan keadilan, hakim harus memiliki kapasitas yang terdiri dari tiga pilar utama, yaitu nilai-nilai kecakapan (competence), kejujuran (integrity) dan kemerdekaan (independence). Bahkan MA RI menyatakan bahwa untuk dapat melakukan tugas fungsional, setidaknya hakim harus menguasai beberapa aspek utama (penguasaan ilmu hukum serta nalar hukum, penguasaan hukum materiil dan formil, serta penguasaan teknis persidangan) dan aspek penunjang (pertanggungan jawab, sikap kepemimpinan dan kemampuan bekerjasama). ${ }^{30}$

Melahirkan hakim yang memiliki kapasitas, realitasnya tidak semudah membalik telapak tangan, karena harus dimulakan dari awal (hilir) berupa rekruitmen sumber daya calon hakim yang transparan dan akuntabel melalui penelusuran rekam jejak (track record) calon hakim yang salah satunya diperoleh dari rekomendasi perguruan tinggi asal secara objektif dengan tanpa "tendensi". Kemudian rekruitmen diselenggarakan bukan hanya terbatas oleh MA tetapi harus melibatkan berbagai komponen, seperti Komisi Yudisial dan kalangan perguruan tinggi yang memiliki kapabilitas dan telah teruji objektifitas dan konsistensinya.

Selain itu dalam rotasi atau mutasi hakim, hendaknya dilakukan secara fair berdasarkan kinerja dan bukan pada pendekatan "like and dislike", sehingga menurut Bagir Manan bahwa pembaharuan di bidang peradilan mencakup antara lain promosi hakim harus semata-mata didasarkan pada pertimbangan kecakapan, integritas dan tingkah laku yang baik - bukan atas dasar lama kerja atau telah memangku jabatan tertentu, apalagi dikaitkan dengan hubungan politis atau loyalitas terhadap kekuatan politik atau hubungan primordial tertentu". ${ }^{31}$

Pelaksanaan kewenangan terkait rekruitmen, Komisi Yudisial mengusulkan metode seleksi pengangkatan calon hakim yang disetarakan dengan pendidikan profesi strata dua (S2) dan bekerjasama dengan perguruan tinggi negeri dan swasta terakreditasi " $A$ " serta untuk diangkat menjadi hakim, harus melalui proses pendidikan hakim terlebih dahulu, seperti bagan berikut dan kemudian diperlukan

29 Peraturan Komisi Yudisial Republik Indonesia Nomor 3 Tahun 2013 tentang Grand Design Peningkatan Kapasitas Hakim.

30 Ibid.

31 Totok Sudaryanto. 2008. Independensi dan Akuntabilitas Kekuasaan Kehakiman. Tanpa tempat terbit: Komisi Hukum Nasional, h.62-63. 


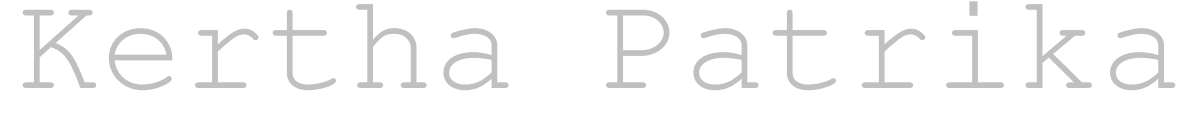

Penyalahgunaan Keadaan oleh Negara Dalam Praktik Perjanjian pada Kajian Hukum Privat Ronald Saija

Program Legislasi Nasional (Prolegnas) 2014-2019, sehingga memberikan kepastian dan perlindungan hukum terhadap para pihak yang melakukan kontrak.

2. Pengadilan menjadi ujung tombak dalam mengisi kekosongan aturan tentang penyalahgunaan keadaan dalam kontrak dan menjadikan pertimbangan-pertimbangan penyalahgunaan keadaan dalam penjatuhan putusan sebagai yurisprudensi tetap. Untuk itu, dibutuhkan peningkatan kapasitas hakim melalui berbagai program kegiatan-baik formal dan informal, agar doktrin penyalah gunaan keadaan lebih familiar dan populer di lingkungan pengadilan, yang dibarengi dengan reward bagi hakim yang memiliki kapasitas dan moral yang baik dan sebaliknya penerapan punishment untuk hakim tidak baik.

\section{DAFTAR PUSTAKA}

\section{Buku}

Ali, Achmad. 2010. Menguak Teori Hukum dan Teori Peradilan. Jakarta: Penerbit Kencana Prenada Media.

Badrulzaman, Mariam Darus. 1994. Aneka Hukum Bisnis. Bandung: Penerbit Alumni.

Balala, Maha-Hanaan. 2011. Islamic Finance and Law Theory and Practice in a Globalized World. New York : I.B. Tauris Co. Ltd.

BPHN Departemen Kehakiman. 1994. Seminar Hukum Nasional. Jakarta: Tanpa penerbit.

Budiono, Herlien. 2006. Asas Keseimbangan bagi Hukum Perjanjian Indonesia. Bandung: Penerbit Citra Aditya Bakti.

Hernoko, Agus Yudha. 2010. Hukum Perjanjian Asas Proporsionalitas dalam Kontrak Komersial. Jakarta: Penerbit Kencana Prenada Media Group.

Manan, Bagir. 2007. Mediasi Sebagai Alternatif Menyelesaikan Sengketa. Jakarta: Penerbit Mahkamah Agung RI.

Marzuki, Peter Mahmud. tanpa tahun. Pembaharuan Hukum Ekonomi Indonesia. Surabaya: Penerbit Universitas Airlangga.

Mertokusumo, Sudikno. 1993. Bab-Bab Tentang Penemuan Hukum. Bandung: Penerbit Citra Aditya Bakti.

Muhammad, Abdulkadir. 2010. Hukum Perjanjian. Bandung: Penerbit Alumni.

Nugroho, Susanti Adi. 2011. Proses Penyelesaian Sengketa Konsumen Ditinjau dari Hukum Acara serta Kendala Implementasinya. Jakarta: Penerbit Kencana Prenada Media. 
